\title{
An ecoregional classification for the state of Roraima, Brazil. The importance of landscape in malaria biology
}

\author{
Maria Goreti Rosa-Freitas $/^{*} /{ }^{+}$, Pantelis Tsouris ${ }^{* *}$, A Townsend Peterson ${ }^{* *}$, \\ Nildimar Alves Honório, Fábio Saito Monteiro de Barros ${ }^{* * *}$,

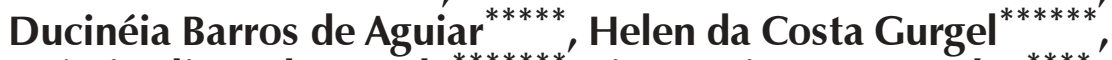 \\ Mércia Eliane de Arruda ${ }^{* * * * * *}$, Simão Dias Vasconcelos ${ }^{* * *}$, \\ José Francisco Luitgards-Moura**
}

\begin{abstract}
Laboratório de Transmissores de Hematozoários, Departamento de Entomologia, Instituto Oswaldo Cruz-Fiocruz, Rio de Janeiro, RJ, Brasil *Freitas-Tsouris Consultants, PO Box 117, Spata, Attica, 19004, Greece **Núcleo Avançado de Vetores, Centro de Ciências Biológicas e da Saúde, Universidade Federal de Roraima, Boa Vista, RR, Brasil ***Natural History Museum and Biodiversity Research Center, The University of Kansas, Lawrence, Kansas, US ****Departamento de Zoologia, Centro de Ciências Biológicas, Universidade Federal de Pernambuco, Recife, PE, Brasil *****Núcleo Estadual de Entomologia, Secretaria de Estado da Saúde de Roraima, Boa Vista, RR, Brasil ******US ESPACE, Institut de Recherche pour le Développement, Paris,

France *******Laboratório de Imunoepidemiologia, Centro de Pesquisas Aggeu Magalhães-Fiocruz, Recife, PE, Brasil
\end{abstract}

Understanding the different background landscapes in which malaria transmission occurs is fundamental to understanding malaria epidemiology and to designing effective local malaria control programs. Geology, geomorphology, vegetation, climate, land use, and anopheline distribution were used as a basis for an ecological classification of the state of Roraima, Brazil, in the northern Amazon Basin, focused on the natural history of malaria and transmission. We used unsupervised maximum likelihood classification, principal components analysis, and weighted overlay with equal contribution analyses to fine-scale thematic maps that resulted in clustered regions. We used ecological niche modeling techniques to develop a fine-scale picture of malaria vector distributions in the state. Eight ecoregions were identified and malaria-related aspects are discussed based on this classification, including 5 types of dense tropical rain forest and 3 types of savannah. Ecoregions formed by dense tropical rain forest were named as montane (ecoregion I), submontane (II), plateau (III), lowland (IV), and alluvial (V). Ecoregions formed by savannah were divided into steppe (VI, campos de Roraima), savannah (VII, cerrado), and wetland (VIII, campinarana). Such ecoregional mappings are important tools in integrated malaria control programs that aim to identify specific characteristics of malaria transmission, classify transmission risk, and define priority areas and appropriate interventions. For some areas, extension of these approaches to still-finer resolutions will provide an improved picture of malaria transmission patterns.

Key words: malaria - ecoregions - Amazon - Roraima - Brazil - Anopheles - Genetic Algorithm for Rule-set Prediction (GARP)

Disease is a spatially-determined phenomenon (Sorre 1933, Pavlovsky 1966). The importance of air, water, and place in medical investigation was first established by Hippocrates in $c .400$ B.C. The correct identification of spatial risk factors and landscape definition plays a key role in prediction, prevention, and control of disease (Le Bras \& Malvi 2004). The concept of landscape includes the set of visible features of an area, including landforms, climates, flora and fauna, weather conditions, and human activity. Landscape epidemiology is based on the idea that diseases tend to be spatially limited, and that this spatial variation arises from abiotic and biotic conditions that can be outlined on maps (Pavlovsky 1966,

+Corresponding author: maria@ freitas-tsouris.com Received 16 February 2007

Accepted 24 April 2007
Ostfeld et al. 2005). Taking into account these elements in landscape epidemiology, assessments of contemporaneous risk and future change in risk should be possible (Ostfeld et al. 2005).

Spatial heterogeneity in natural and human-dominated landscapes is an important characteristic in malaria epidemiology (Smith et al. 2004). Development of ecoregional maps based on landscape elements, distributions of vectors, and malaria incidence to improve understanding and prediction of malaria transmission at the landscape scale is the target of the present communication. The example of the state of Roraima in the northern Brazilian Amazon Basin is used to build a rationale that can be useful for future work on malaria using the ecoregional landscape approach.

Roraima is the Brazilian state having one of the highest malaria annual parasitic indices (API, number of malaria cases per 1000 inhabitants) in recent years (Ministério da Saúde 2006) (Fig. 1). Roraima's vegetation is diverse, reflecting variation in landscape, soil, land cover, and climate, ranging from dense tropical forests to open savannah. Of the 9 phytoecological types found in Brazil, 6 are represented in Roraima (IBGE 2005). 

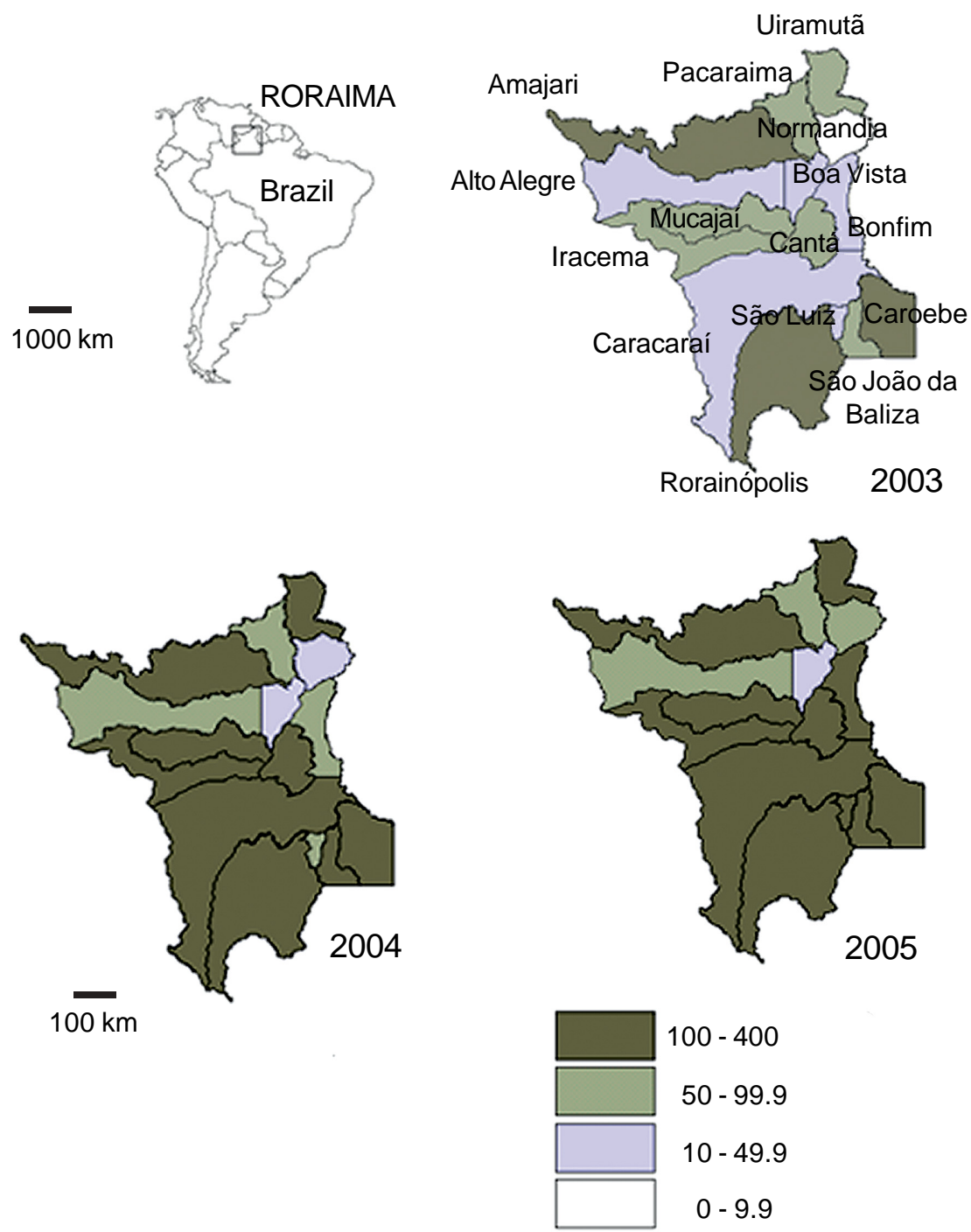

$100-400$

$50-99.9$

$10-49.9$

$0-9.9$

Fig. 1: South America, Brazil, showing the state of Roraima (square), municipality limits, and recent malaria annual parasitic index (number of cases per 1000 inhabitants, according to Funasa 2006).

Ecoregional classification systems are increasingly used for policy and management decisions, particularly among conservation and natural resource managers (Thompson et al. 2004). Climate, soil, altitude, dominant vegetation (Stein et al. 2000), biodiversity (Olson et al. 2001), and malaria ecology (Rubio-Palis \& Zimmerman 1997) have been used to classify regions. The term ecoregion as used here is "a relatively large unit of land or water containing a geographically distinct assemblage of species, natural communities, environmental conditions, and ecosystems sharing certain distinct characters and ecological interactions essential for their long term persistence" (Omernik 1987, Dinerstein et al. 1995, Bailey 1998). Among other uses, ecoregional classifications in epidemiology of diseases can help in understanding patterns of transmission in a particular environment, predicting phenomena based on statistical relationships between incidence of medically relevant species and correlated characteristics of the ecoregions (Schroder 2006), and assisting in human settlement decisions and control programs. Different ecoregions may present better or worse conditions for development of serious epidemics (Schroder 2006).

Ecoregional classifications are hierarchical, with their spatial scale dependent on the resolution required. At the level of continents, ecoregions are called biogeographic realms, at the level of countries, biomes. We will refer to levels I, II, and III of ecoregional classification (Omernik 1987), in which level I highlights major ecological areas, level II provide a more detailed description of ecological areas within the level I regions, and level III areas describes finer-scale ecological variation within level II regions. 
Malaria worldwide was the focus of an ecological classification by MacDonald (1957), who defined 12 areas where malaria transmission is similar, based on temperature, rainfall, seasons, and physical features of the landscape, as well as on distributions of important anopheline vector species. In the northern Amazon Basin, previous ecoregional classifications placed all of Roraima in one broad ecoregion named the Marajó Várzea forests (Soares-Filho et al. 2006). Within Roraima, previous ecoregional classification efforts also identified subdivisions (Olson et al. 2001, Soares-Filho et al. 2006). Focusing on malaria, based on human demography, distributions of vector species, and ecological parameters of the landscape, 2 malaria ecoregions were delineated for Roraima: lowland forest versus savannah (Rubio-Palis \& Zimmerman 1997).

From previous entomological studies in Roraima, we have observed diverse ecological landscapes that likely translate into distinct malaria transmission patterns. For instance, malaria transmission in the surroundings of Boa Vista, a savannah area, would differ from its transmission in the Yanomami Indian reserve in the northwestern mountains, a dense rain forest area. Indeed, the variation in richness and diversity of vegetation and landscape, combined with heterogeneous malaria vector and human distributions lead us to consider that a finer-scale ecoregional classification could improve the understanding of malaria transmission in Roraima.

\section{MATERIALS AND METHODS}

Description of the study area - Roraima is Brazil's northernmost state, located at 59 to $65^{\circ} \mathrm{W}$ longitude and $-1^{\circ} \mathrm{S}$ to $5^{\circ} \mathrm{N}$ latitude. Roraima is divided into 15 municipalities, and has an overall extent of approximately $225,116 \mathrm{~km}^{2}$ (Fig. 1). Roraima lies mostly in the Amazon Basin, in the Branco-Negro river lowlands, and is mostly humid (Fig. 2). Schmidt (1942) described its climate as presenting two distinct seasons: a rainy season in April-November, with highest rainfall indices in June and July, and a dry season in December-March. Marked differences of rainfall exist between northern savannahs $(\sim 1000 \mathrm{~mm} /$ year) and southern forests $(>2000 \mathrm{~mm} /$ year) in Roraima (Barbosa et al. 1997).
Ecoregional classification data- Data sets used for developing the ecoregional classification included: (1) landscape elements (geology, geomorphology, vegetation, climate, rivers), (2) human presence (roads, cities, land use), and (3) vector distribution (anopheline collection points and predicted distributions) (Figs 2, 3).

Landscape elements - Digital fine-scale maps of geology, geomorphology, vegetation, rivers, and climate were rasterized in grid data sets of $0.01^{\circ}(\sim 1.25 \mathrm{~km})$ resolution (Fig. 2, Agrotecnológica Amazônica Inc. 2006, IBGE 2006a, Ministério do Meio Ambiente 2006).

Human occupancy - Digital thematic maps of land use, roads, and cities were rasterized in grid maps of $0.01^{\circ}(\sim 1.25 \mathrm{~km})$ resolution (Fig. 2, IBGE 2006a, Ministério do Meio Ambiente 2006). These maps show that Roraima's population is not distributed homogeneously. Human populations are concentrated around the capital, Boa Vista (61\% of 391,317 inhabitants), as well as in 35 agricultural settlements (22\%) and indigenous reserves (10\%) (IBGE 2006b) (Fig. 2). Of Roraima's total area, $45.2 \%$ is allocated to 32 Indian reserves, comprising 38,000 native Americans of 8 ethnic groups. In 5 municipalities (Normandia, Uiramutã, Alto Alegre, Pacaraima, and Iracema), Indian reserves occupy $>70 \%$ of the area (IBGE 2005). Thus, patterns of malaria transmission in indigenous communities are an important component in the malaria control strategy for Roraima. The remaining $7 \%$ of the human population lives in urban areas in the form of small cities and villages along river margins and roads (IBGE 2006b, Crocia-Barros 1996). Cattle ranching in savannah areas was the economic activity responsible for the first immigration waves into Roraima; more recently, mining and government-related services have drawn additional human settlement (Crocia-Barros 1996).

Vector distribution prediction - Anopheline predicted distributions were based on 76 sampling points for the 8 species that were collected at $\geq 19$ points. We developed ecological niche models and geographic predictions using the Genetic Algorithm for Rule-set Prediction (GARP, Stockwell and Peters 1999; Table I). Meteorological and bioclimate variables used in model

TABLE I

Comparison of data analyses results

\begin{tabular}{|c|c|c|c|c|c|c|c|c|}
\hline Method & Clusters & 1 & 2 & 3 & 4 & 5 & 6 & 7 \\
\hline $\begin{array}{l}\text { Maximum } \\
\text { likelihood }\end{array}$ & Ecoregions & I & II + III & IV & $\begin{array}{l}\mathrm{V}+\text { part } \\
\text { of VIII }\end{array}$ & VI & $\begin{array}{l}\text { VII }+ \\
\text { part of } \\
\text { VIII }\end{array}$ & extra cluster $^{a}$ \\
\hline $\begin{array}{l}\text { Principal } \\
\text { components } \\
\text { analysis }\end{array}$ & & I + III & II & $\begin{array}{l}\text { part of } \\
\text { IV }\end{array}$ & $\begin{array}{l}\mathrm{V}+\text { part } \\
\text { of IV }\end{array}$ & VI & VII & extra cluster $^{a}$ \\
\hline Weighted overlay & & $\begin{array}{l}\mathrm{I}+\mathrm{II} \\
+\mathrm{III}+ \\
\mathrm{V}\end{array}$ & IV & $\begin{array}{l}\text { VI + extra } \\
\text { cluster }\end{array}$ & $\begin{array}{l}\text { VII (part) } \\
+ \text { VIII }\end{array}$ & & & extra cluster ${ }^{a}$ \\
\hline
\end{tabular}

a: formed by patches in the northern, eastern, and southern sectors of the state that are included in other ecoregions, principally IV. 


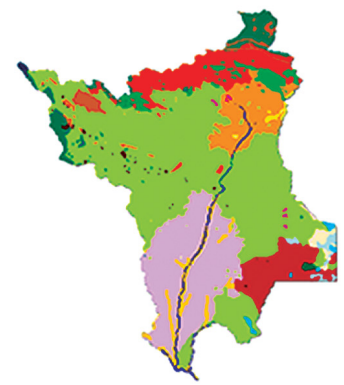

Geology
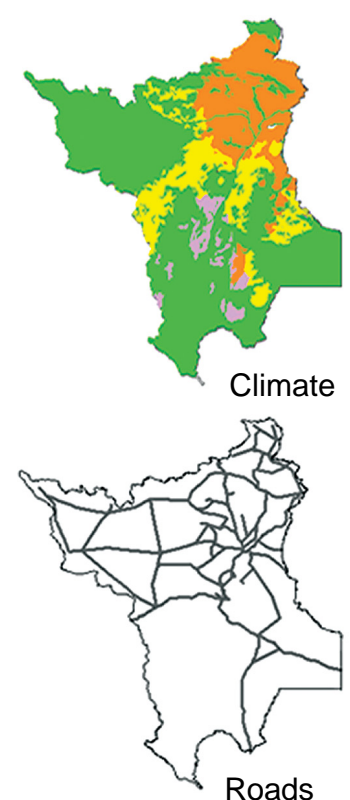

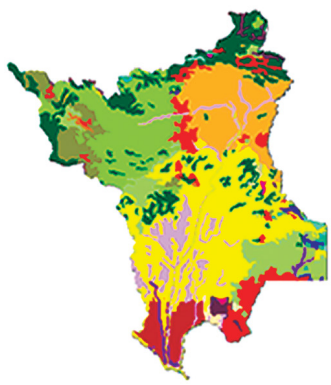

Geomorphology

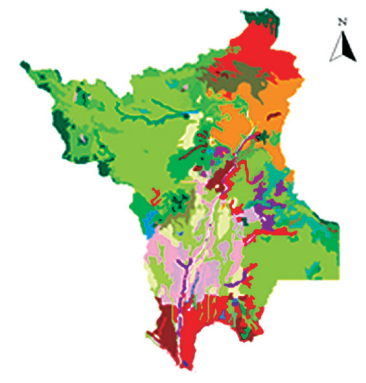

Vegetation $\overline{100 \mathrm{~km}}$
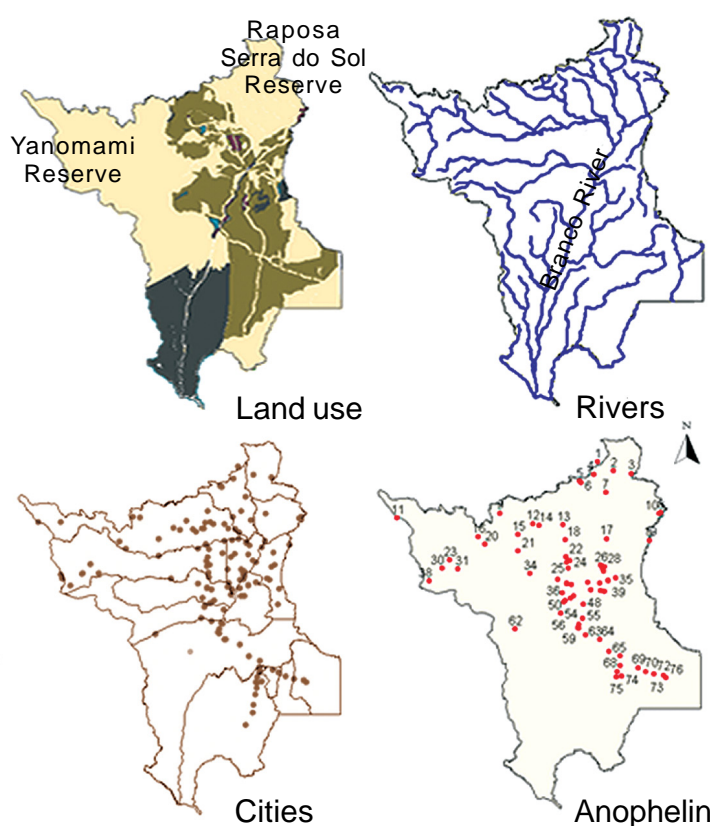

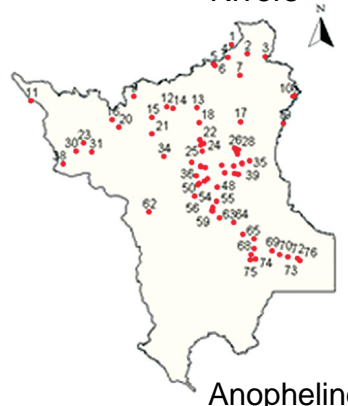

Anopheline Collection Points

Fig. 2: datasets used for ecoregional classification of Roraima, Brazil. Color code is different for each data source.

development were 24 months of NDVI (greenness index) data from the AVHRR satellite (April 1992-March 1993, February 1995-January 1996), a suite of data that has proven useful in previous studies of vector distributions (Peterson et al. 2005). The sample size requirement allows reasonable confidence in the accuracy of the predictive models (Stockwell \& Peterson 2002). In all, half of the points were used for training and the other half for model evaluation in 1000 runs, and best subset filtering (Anderson et al. 2003) was used to derive final predictions. Species examined were An. darlingi, An. albitarsis s.l., An. triannulatus s.l., An. nuneztovari s.l., An. braziliensis, An. oswaldoi, and An. peryassui. Predicted distribution maps (raster grids, $0.01^{\circ}, \sim 1.25 \mathrm{~km}$ ) (Fig. 3) for each species were used in comparisons with the results of analysis of the other variables in the ecoregional classification.
Ecoregional classification - We produced composite-band rasters of the data set in groups of 3 themes at the time, isoclustered composite rasters, and then used unsupervised maximum likelihood classification (ML), principal components analysis (PCA), and weighted overlay with equal contribution (WO) analyses to fine-scale thematic maps to produce sets of clustered regions (Spatial Analyst, ArcGIS 9, ESRI 2006, Redlands, CA, US). We then made extensive, careful comparisons with existing phytogeographic- (IBGE 2006a, Ministério do Meio Ambiente 2006), malaria- (Rubio-Palis \& Zimmerman 1997) and conservation-based (Olson et al. 2001) classifications, and adjusted the raw, quantitative output by eye, based on mosquito distributional patterns and patterns of human settlement to identify areas relevant to variation in malaria transmission patterns and processes. 

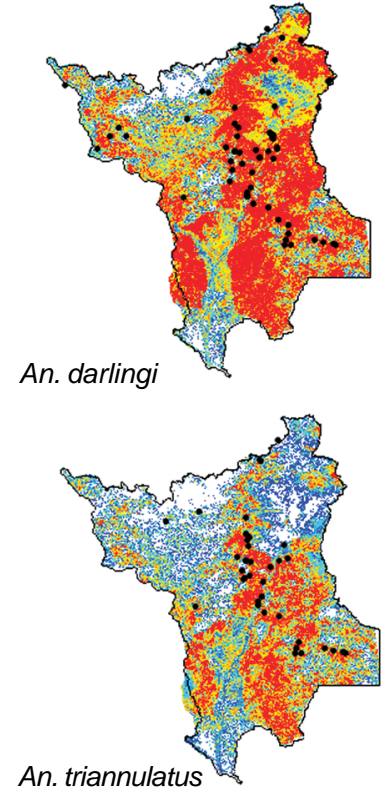

An. albitarsis

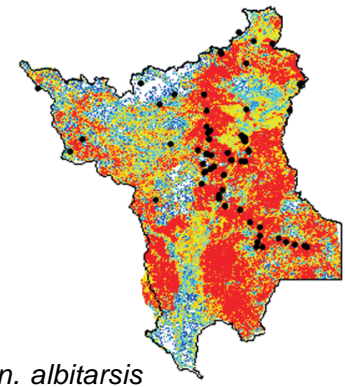

An. nuneztovari

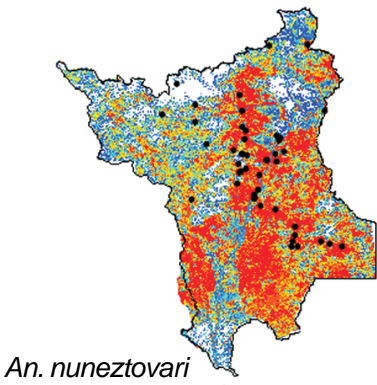

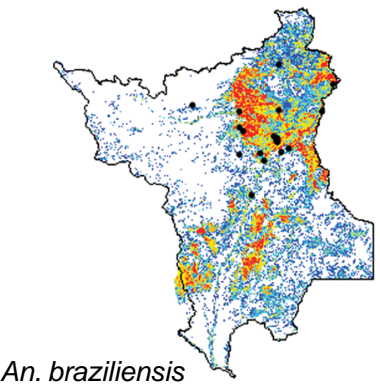

An. braziliensis

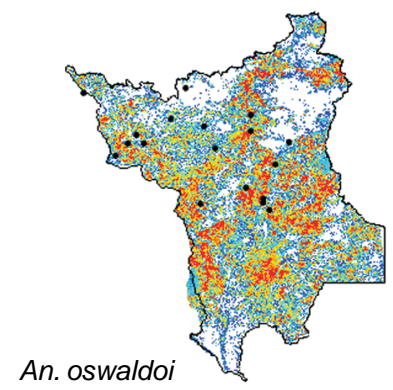

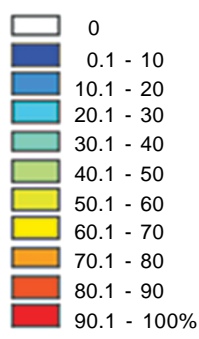

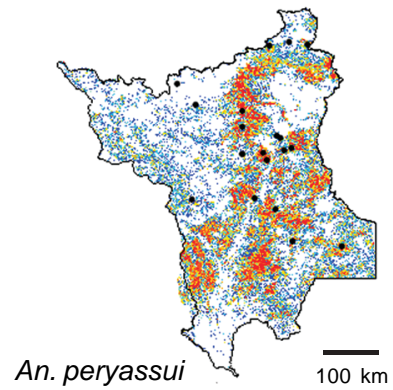

Fig. 3: predicted distributional areas for seven anopheline species (Barros et al. in press). Known occurrences of each species are shown as blacks dots.

\section{RESULTS}

Landscape elements - ML, PCA, and WO analyses of rasterized thematic maps resulted in clustered regions (Fig. 4, Table I). ML grouped savannah and wetland habitats, and separated steppe savannahs. ML also grouped submontane forest with plateau forest, lumped montane and part of lowland forests and alluvial and part of wetlands together, and made a group from the area along northern, eastern and southern borders with many sparse vegetation types. This extra cluster was joined with the lowland in our classification. PCA separated areas corresponding to steppe, savannah, and wetland. PCA grouped montane and lowland forests and recognized areas at the northern, eastern and southern borders consisting of many sparse vegetation types. PCA grouped alluvial forest with wetlands, considering them of the same kind, and separated plateau formations. WO grouped montane, submontane plateau, and alluvial forests; combined lowelevation savanna with lowland forest, and grouped the high-elevation part of the savanna with wetlands. WO also grouped the steppe with a southern area containing many sparse vegetation types, and separated an area in the eastern savannah that has unique geological features.

Human occupancy - Indian reserves are located in the northern parts of Roraima. Villages and cities of all sizes follow roads and rivers, concentrated in a northsouth stripe (Fig. 2). Human populations are focused along rivers and in savannah, and not in the highlands.

Anopheline distributions - Predicted distributions of mosquito species clustered along a diagonal northsouth stripe. Maps for An. albitarsis and An. darlingi showed very similar distributions across central and eastern Roraima (Fig. 3). An. braziliensis showed 2 distributional areas corresponding to areas surrounding sa-

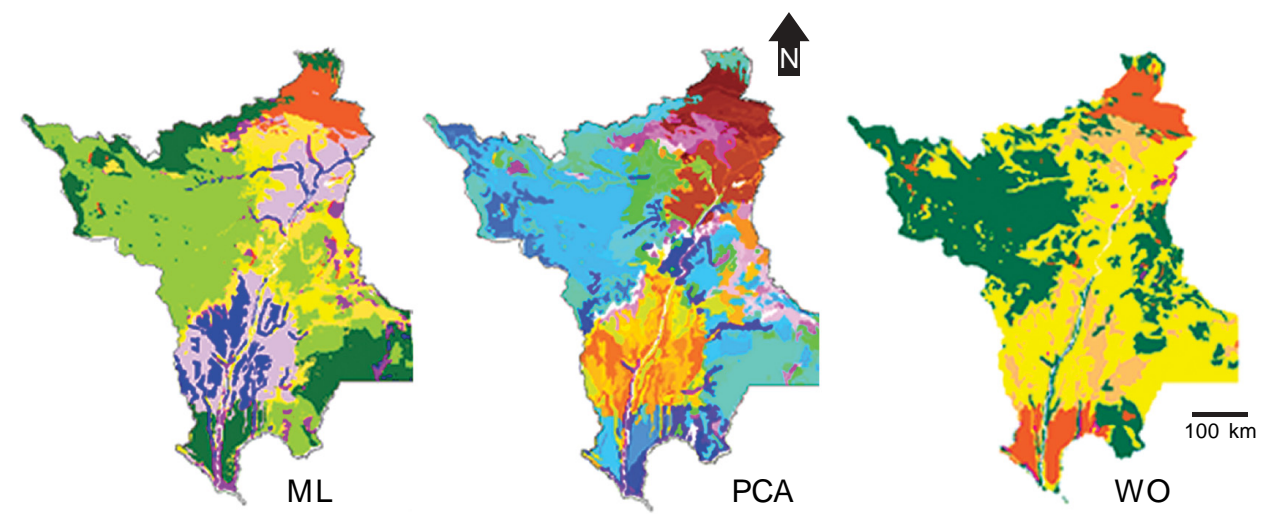

Fig. 4: clustered regions based on principal component (PCA), unsupervised maximum likelihood classification (ML) and weighted overlay (WO) analyses. 
vannah and wetlands, the former a more humid savannah area visible in higher-resolution maps (not shown). An. triannulatus and An. nuneztovari showed restricted distributional areas in northern montane and submontane areas and southern alluvial areas (where the Rio Branco is wide), and a major focus in the lowlands (Fig. 3). An. oswaldoi was predicted to occur throughout the central lowlands, but also in scattered sectors of the montane, plateau, and southern alluvial areas (Fig. 3). An. peryassui was predicted to be concentrated in humid savannah areas (Fig. 3).

Ecoregional classification for Roraima - Adding mosquito distributions into principal component, maximum likelihood classification, and weighted overlay analyses based on geology, geomorphology, vegetation, climate maps resulted in 8 regions being identified. This classification adds one ecoregion in alluvial forests, based on consideration of anopheline distributions and given the known importance of alluvial forest to malaria vector species (Fig. 5, Table II). These 8 ecoregions were thus named montane (dense tropical rain forest, ecoregion I), submontane (dense tropical rain forest, II), plateau (tropical rain forest, III), lowland (tropical rain forest, IV), alluvial (tropical rain forest, V), savannah (cerrado or lavrado, VI), steppes (campos de Roraima, VII), and wetland (campinarana, VIII; Fig. 5). In the descriptions that follow, mosquito vector species' distributions are based on both known occurrences and modeled distributions (see Barros et al. in press) (Fig. 3).

Ecoregion I - This ecoregion is formed mainly by dense montane tropical rain forest along the northern border of Roraima, and also exists in patches farther south. It is of high elevation (> $1500 \mathrm{~m}$ ), with low human population density. Its main human occupancy is indigenous populations living in scattered groups in the Yanomami Indian Reserve that extends into ecoregion II to the northwest and the São Marcos and Raposa/Serra do Sol Indian reserves, to the northeast. An. darlingi, An. albitarsis, An. triannulatus, and An. oswaldoi are the principal vectors in this region.

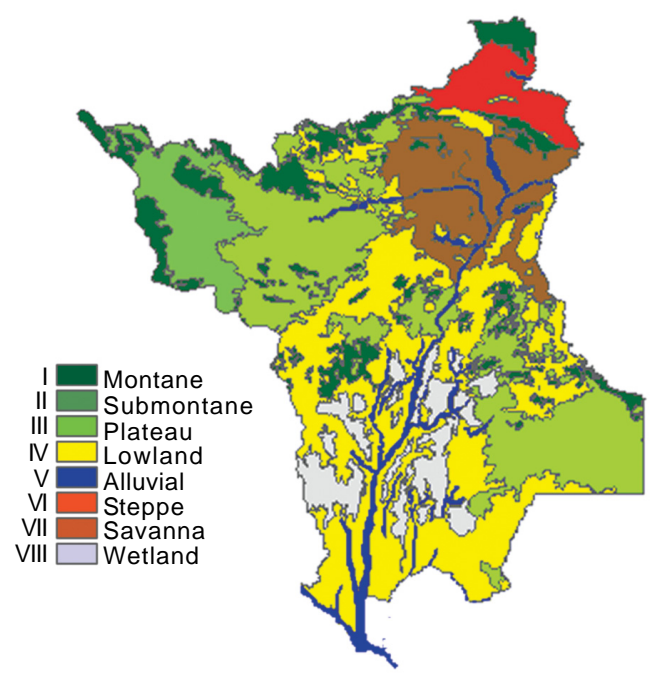

Fig. 5: ecoregions of Roraima developed in this study.
Ecoregion II - This ecoregion is formed by dense submontane tropical rain forest in the northwestern part of the state. It is entirely occupied by the Yanomami Indian Reserve in the northwest, and is at $\sim 500-650 \mathrm{~m}$ elevation. It also occurs in isolated patches (serras) in central and southeastern Roraima. Vector species present are An. darlingi, An. albitarsis, An. triannulatus, An. nuneztovari, and An. oswaldoi.

Ecoregion III - This ecoregion is made up of dense tropical rain forest on an intermediate plateau at $\sim 150$ $350 \mathrm{~m}$ elevation. Human occupation is comprised of the Yanomami Indian Reserve in the northwest and agricultural settlements in the southeast. All vector species are likely present except An. braziliensis.

Ecoregion IV - This ecoregion is covered by lowland tropical rain forest over much of Roraima's territory, up to $\sim 150 \mathrm{~m}$ elevation. Most of the state's human population is concentrated in this ecoregion, either along the rivers that were the preferred settlement areas in the past, or along the main roads where more recent settlements have focused (Crocia-Barros 1996). All vector species except An. braziliensis likely occur.

Ecoregion $V$ - Alluvial tropical rain forest lines river banks crossing most of the other ecoregions. In the past, with rivers being used as transport pathways, many cities were founded along rivers, so alluvial forest is still present within urban areas in Roraima. A large portion of the state's human population thus occurs in or near this ecoregion. Alluvial forest corridors can be up to 500 $\mathrm{m}$ wide in low-elevation areas, are subject to seasonal flooding, and may support significant mosquito vector populations. The link between important malaria vectors and alluvial forest is well-known (Amaral \& Penido 1947, Andrade \& Leal 1960, Rubio-Palis \& Zimmerman 1997, Barros \& Honório 2007).All vector species except $A n$. peryassui likely occur in this region.

Ecoregion VI - This ecoregion is composed of steppe (campos de Roraima), extending across the northeastern part of the state. It is a high-elevation ecoregion (up to $\sim 1000 \mathrm{~m}$ ), descending to $\sim 300 \mathrm{~m}$ at its southern border. Some medium-sized cities (e.g. Uiramutã, Pacaraima) are present, including airports and the Raposa/ Serra do Sol Indian Reserve. An. darlingi and An. albitarsis are likely to occur across much of this ecoregion, but other species are likely to be less extensive.

Ecoregion VII - This ecoregion is dominated by savannah (cerrado) in the northeastern part of the state. This ecoregion is mainly low-elevation (up to $\sim 150 \mathrm{~m}$ ) and up to $\sim 300 \mathrm{~m}$ at the northern border. This ecoregion holds Boa Vista, where $61 \%$ of the state's inhabitants live (IBGE 2006b). An. braziliensis is predicted to be concentrated in this ecoregion and ecoregion VIII, while other species are less likely to be present.

Ecoregion VIII - This ecoregion is formed by wetland savannah (campinarana) in the central-western part of the state at low elevations (up to $\sim 150 \mathrm{~m}$ ). Except for the village of Santa Maria do Boiaçu (Caracaraí) and scattered settlements along Rio Branco accessible by boat 


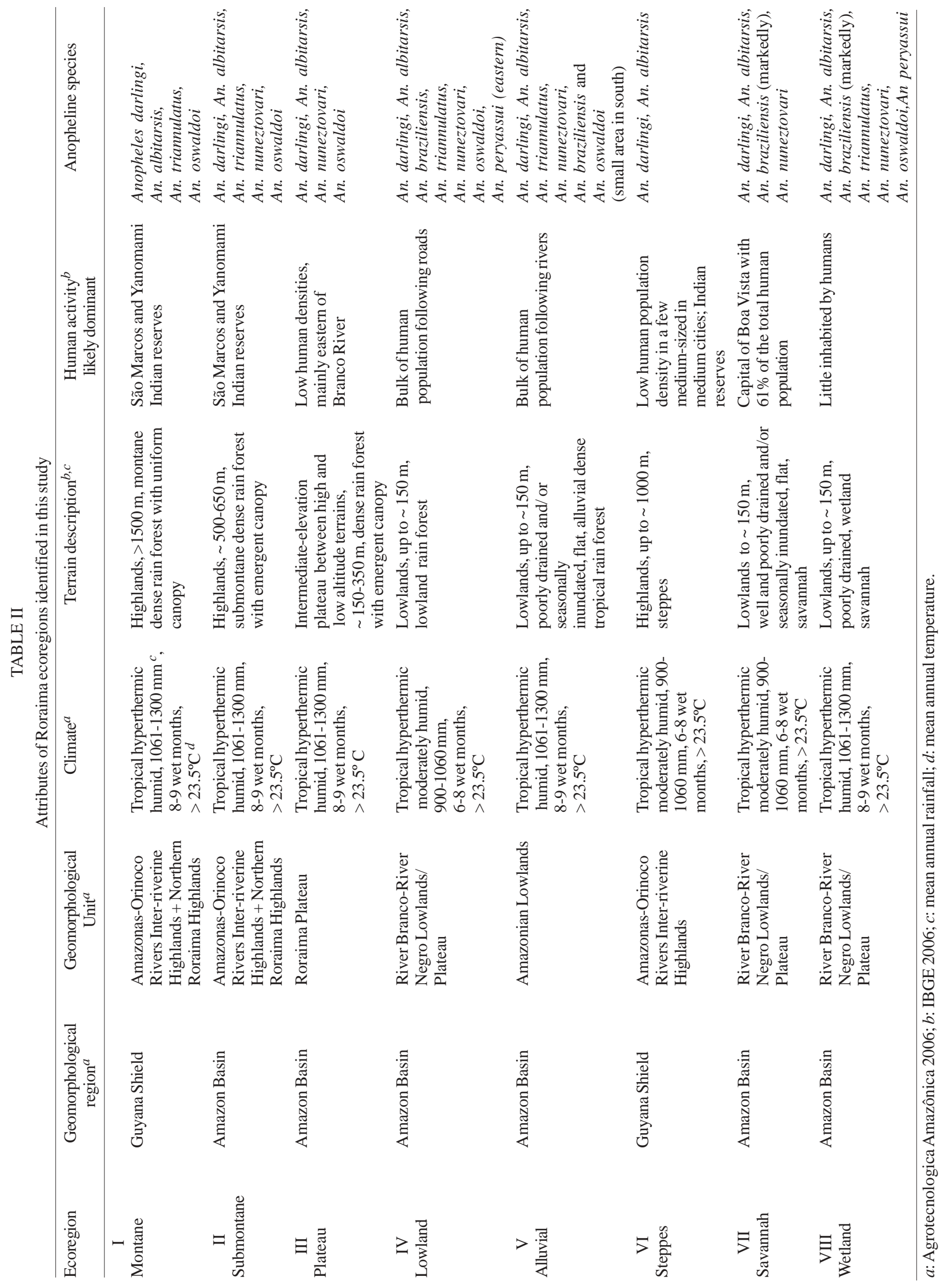


only, no human presence exists in this area (FS Monteirode-Barros, pers. observ.). An. braziliensis is predicted to be concentrated here, while other species are unlikely to be broadly distributed or common.

\section{DISCUSSION}

Roraima presents a diverse ecological mosaic, reflecting variation in landscape, climate, anopheline distributions, and human distribution. Roraima's vegetation is diverse also, and is still mostly in a natural condition, including different sorts of forests (83\%) and savannahs (17\%). The diversity is confirmed by the fact that Roraima holds 6 of the 9 phytoecological regions represented in Brazil (IBGE 2006a). At finer scales, other formations are created by ecotones and other smaller-extent phenomena, such as alluvial forests (IBGE 2006a). Here, we have proposed a state-level ecoregional classification for Roraima oriented specifically at malaria epidemiology and control.

Our methods and results differ from those of previous studies. Previous malaria-oriented classifications divided Roraima into 2 ecoregions, namely interior lowland forest and savannah (Rubio-Palis \& Zimmerman 1997). Classifications aimed at conservation either did not subdivide Roraima (Soares-Filho et al. 2006) or split the state into 7 ecoregions [Guianan savannah, Guianan piedmont and lowland moist forest, Guianan highlands moist forest, pantepui, Negro River campinarana, Uatumã-Trombetas moist forest, Negro-Branco Rivers moist forest (Olson et al. 2001)].

Our classification is based on geomorphology, vegetation, climate, human distributions, and malaria vector distributional patterns (Figs 2,3); this schema differs from the conservation-based efforts by taking into account human presence and mosquito distributions. Our 8-unit ecoregion classification, although close to that of Olson, further divides the Guianan savannah into 2 ecoregions (steppe and savannah), and classifies alluvial forests as a separate ecoregion; however, we do not recognize Negro-Branco River moist forest as separate, instead combining it with other lowland forests (ecoregion IV). It has been suggested that alluvial forests play important roles in malaria transmission (Barros \& Honório 2007), as they are subject to seasonal flooding in the late rainy season, creating suitable breeding habitats for mosquitoes. We observed patches of specific subformations within the 8-unit ecoregion divisions that, excepting the alluvial forests, were not considered in this regional scale analysis and are nested within the 8 level-II ecoregions; at least 25 level-III ecoregions could be recognized (not shown).

All 8 of the Roraima ecoregions show suitable conditions for continuous malaria endemicity, as is clear from the ample distribution of the disease in the state (Funasa 2006). The primary vectors, An. darlingi and An.albitarsis, are spread across all of Roraima and have been documented as infected in Boa Vista (SilvaVasconcelos et al. 2002, Póvoa et al. 2006). An. darlingi is anthropophilic, and is the main P. falciparum and $P$. vivax malaria vector in endemic areas in Amazonia. Dis- tributional predictions based on ecological niche models show the near-ubiquitous range of this species in Roraima (Fig. 3). An. albitarsis was also predicted to occur amply in all 8 ecoregions (Fig. 3).

Other species are not as widespread, but may be locally important. An. braziliensis is concentrated in areas in and surrounding ecoregions VI and VII (savannah and wetlands) and to a lesser degree in ecoregion VIII. An. triannulatus and An. nuneztovari are spottily distributed in ecoregions I and II (montane and submontane), but more broadly in ecoregions IV and VIII. An. oswaldoi was predicted principally in ecoregion IV, whereas $A n$. peryassui is anticipated mainly in ecoregion IV (Figs 3, 5). We added and defined an extra ecoregion constituted based on the consideration that some vector species are focused distributionally in this habitat, as well as on the known importance of alluvial forest in malaria transmission (Amaral \& Penido 1947, Andrade \& Leal 1960, Rubio-Palis \& Zimmerman 1997).

Local ecoregional mapping as a technique in spatial epidemiology can be an important tool for malaria integrated control programs (Ostfeld et al 2005). It helps to classify risk and identify priority intervention areas based on functional aspects of ecosystems that likely affect malaria transmission biology. For some areas, it will be necessary to increase stratification to finer resolutions for a fuller understanding of malaria transmission patterns.

\section{ACKNOWLEDGMENTS}

Two anonymous referees provided helpful suggestions regarding an earlier draft of the manuscript.

\section{REFERENCES}

Agrotecnológica Amazônica Inc. 2006. Amazon: Land in tropical Americas. Available at www.agteca.com/amazon.htm. Accessed 20 November 2005.

Amaral AD, Penido HN 1947. Distribuição dos anofelinos no Vale do Rio Doce: espécies transmissoras da malaria. Rev Serv Especial Saúde Púb 1: 163-176.

Anderson RP, Lew D, Peterson AT. 2003. Evaluating predictive models of species' distributions: Criteria for selecting optimal models. Ecol Mod 162: 211-232.

Andrade RM, Leal JM 1960. Distribuição dos anofelinos na bacia hidrográfica do Rio São Francisco, estado de Minas Gerais, Bahia, Goiás, Pernambuco, Alagoas e Sergipe (Brazil). Rev Bras Malariol Doencas Trop 12: 147 - 164.

Barros FSM, Honório NA 2007. Man biting rate seasonal variation of malaria vectors in Roraima, Brazil. Mem Inst Oswaldo Cruz 102: in press.

Bailey RG 1998. Ecoregions: The Ecosystem Geography of the Oceans and Continents, Springer-Verlag, New York, 120 pp.

Barbosa RI, Ferreira EJG, Castellón EG 1997. Homem, Ambiente e Ecologia no Estado de Roraima, Inpa, Manaus, 613 pp.

Crocia-Barros NC 1996. Mobilidade populacional, fronteira e dinâmica das paisagens na Amazônia: o caso de Roraima, Brasil. Cad Est Soc Fund Joaquim Nabuco 12: 237-284.

Dinerstein E, Olson DM, Graham DJ, Webster AL, Primm SA, Bookbinder MP, Ledec G 1995. A Conservation Assessment of the Terrestrial Ecoregions of Latin America and the Caribbean, WWW \& World Bank, Washington,129 pp. 
ESRI-Environmental Systems Research Institute 2006. ArcMap 9.0, Redlands CA 92373-8100.

Funasa-Fundação Nacional de Saúde 2006. Sistema de informações de vigilância epidemiológica - Malária (SIVEPMalária), Secretaria de Vigilância em Saúde, Ministério da Saúde.Vigilância. Programa Nacional de Controle da Malária. Available at http://saude.gov.br/svs. Accessed 21 April 2006.

IBGE-Instituto Brasileiro de Geografia e Estatística 2005. Projeto Levantamento e Classificação da Cobertura e do Uso da Terra. Uso da Terra no Estado de Roraima Relatório Técnico. Rio de Janeiro. Available at http://www.ibge.gov/. Accessed 1 August 2006.

IBGE-Instituto Brasileiro de Geografia e Estatística 2006a. Download Geociências. Available at http://www.ibge.gov.br/ servidor_arquivos. Accessed 12 June 2005.

IBGE-Instituto Brasileiro de Geografia e Estatística 2006b. Cidades@. Available at http://www.ibge.gov.br/cidadesat/ default.php. Accessed 12 June 2005.

Le Bras M, Malvi JMD 2004. Le complexe pathogène tropical regard nouveau sur un concept ancien. Med Trop 64: 613-618

Macdonald G 1957. The Epidemiology and Control of Malaria, University Press, Oxford, 201pp.

Ministério da Saúde 2006. A malária no Brasil. Available at http:/ /portal.saude.gov.br/portal/ arquivos/pdf/ be_malaria_ 01_2005. pdf. Accessed 2 July 2005.

Ministério do Meio Ambiente 2006. DataDownload. Available at http://mapas.mma.gov.br/i3geo/datadownload.htm Accessed 10 March 2007.

Olson DM, Dinerstein E, Wikramanayake ED, Burgess ND, Powell GVN, Underwood EC, D'amico JA, Itoua I, Strand HE, Morrison JC, Loucks CJ, Allnutt TF, Ricketts TH, Kura Y, Lamoreux JF, Wettengel WW, Hedao P, Kassem KR 2001. Terrestrial ecoregions of the world: a new map of life on earth. BioScience 51: 933-938

Omernik JM 1987. Ecoregions of the conterminous United States. Ann Soc Am Geogr 77: 118-125.

Ostfeld RS, Glass GE, Keesing F 2005. Spatial epidemiology: an emerging (or re-emerging) discipline. Trends Ecol Evol 20: 328-36.

Pavlovsky EN 1966. Natural Nidality of Transmissible Diseases with Special Reference to the Landscape Epide- miology of Zooanthroponoses translated by Frederick K Plous, Jr. ND Levine ed., University of Illinois Press. 261 pp.

Peterson AT 2001. Predicting species' geographic distributions based on ecological niche modelling. Condor 103: 599-605.

Peterson AT, Martínez-Campos C, Nakazawa Y, Martínez-Meyer E. 2005. Time-specific ecological niche modeling predicts spatial dynamics of vector insects and human dengue cases. Trans R Soc Trop Med Hyg 99: 647-655.

Póvoa MM, Souza RTL, Lacerda RNL, Santa-Rosa E, Galiza D, Souza JR, Wirtz RA, Schlichting CD, Conn JE 2006. The importance of Anopheles albitarsis and An. darlingi in human malaria transmission in Boa Vista, state of Roraima, Brazil. Mem Inst Oswaldo Cruz 101: 163-168.

Rubio-Palis Y, Zimmerman RH 1997. Ecoregional classification of malaria vectors in the Neotropics. J Med Entomol 34: 499-510.

Schmidt JCJ 1942. O clima da Amazônia. Rev Bras Geogr 4: 465-500.

Schroder W 2006. GIS, geostatistics, metadata banking, and treebased models for data analysis and mapping in environmental monitoring and epidemiology. Int J Med Microbiol 296: (Suppl. 40):23-36.

Silva-Vasconcelos A, Kato MYN, Mourão EN, Souza RTL, Lacerda RNL, Sibajev A, Tsouris P, Póvoa MM, Momen H, Rosa-Freitas MG 2002. Biting indices, host-seeking activity and natural infection rates of anopheline species in Boa Vista, Roraima, Brazil from 1996 to 1998. Mem Inst Oswaldo Cruz 97: 151-161.

Smith DL, Dushoff J, McKenzie FE 2004. The risk of a mosquito-borne infection in a heterogeneous environment. PLoS Biol 2: 1956-1964.

Soares-Filho BS, Nepstad DC, Curran LM, Cerqueira GC, Garcia RA, Ramos CA, Voll E, McDonald A, Lefebvre P, Schlesinger P 2006. Modelling conservation in the Amazon basin. Nature 440: 520-523.

Stockwell DRB, Peters DP 1999. The GARP modelling system: problems and solutions to automated spatial prediction. Int $J$ Geogr Info Syst 13:143-158.

Thompson RS, Shafer SL, Anderson KH, Strickland LE, Pelltier RT, Bartlein PJ, Kerwin MW 2004. Topographic, bioclimatic, and vegetation characteristics of three ecoregion classification systems in North America: comparisons along continentwide transects. Environ Manag 34 (Suppl. 1): S125-S148 
